\title{
The Ideological Reproduction: (Free) Labouring and (Social) Working within Digital Landscapes
}

\author{
Marco Briziarelli \\ University of New Mexico, Albuquerque, USA, mbriziarelli@unm.edu
}

\begin{abstract}
The present paper explores the role of (neo-)liberal ideology in reproducing digital labour. Drawing on Terranova's concept of "free labour", and Fuchs and Sevignani's distinction between "work" and "labour", the author claims that theorization of Web 2.0 practices requires the exploration of ideology as a material force and a contradictory phenomenon. More specifically, the paper considers the capability of ideology to mediate between the valorization and exploitation of user-generated content and the utopian thrust that re-signifies unpaid labour into apparently engaged practices resonating with liberal ideology. In the last section, the paper takes Facebook as an exemplification of such an ideological synthesis of exploitative and normative aspects.
\end{abstract}

Keywords: Digital Labour, User Generated Content, Free Labour, Ideology, Marx, Facebook

\section{Introduction}

The present paper tries to answer an apparently simple question: granting the applicability of Smythe's "audience labour" analysis (1977) on digital contests (Fuchs 2010, 2012), what is it that drives web 2.0 prod-users to labour for free, to be exploited and to be treated as a commodity sold to the advertising industry? Why do they accept to generate content that instead of enriching the "general intellect" becomes appropriated for the personal gain of few? Is it a question of "false consciousness" or Žižek's "ideological cynicism"?

I intend to respond to these questions by exploring the reproductive function of ideology in Web 2.0 media practices. I claim that the theorization of digital labour requires the exploration of a multifaceted and contradictory ideological phenomenon. While producing content for the Web, digital labour produces (and simultaneously being a product of) a particular ideology that informs the web 2.0 user's consciousness. Such a worldview is at the same organic to the valorization and exploitation of user-generated content and propelled by a utopic thrust that resonates with the liberal understanding of sociability.

Pushing against a tendency in media studies to privilege an idealist understanding of ideology, this essay examines it as a material force that reproduces labour by extrapolating from "necessity", an apparent "liberty" of production. I will describe such a process by drawing on Terranova's notion of "free labour", Fuchs and Sevignani's (2013) distinction between "labour" and "work", and Bloch's (1986) understanding of ideology. In my view, such a combination of dystopic and utopic elements reflexes the capability of this specific ideology to conciliate the aspect of unpaid "labouring" and the apparently emancipatory "social working" aspect of web 2.0 platforms.

In order to advance my argument, I structure this paper in three main sections: the first one concerning digital labour; the second one exploring the ideological dimension of digital labour; and the third one that uses Facebook as an exemplification of such ideological dynamics. After an introduction to digital labour and a review of some of the central issues around it, the paper discusses how ideology has been conceptualized in media studies. Drawing on Bloch, I argue that making sense of ideology requires consistently maintaining a position in between material and symbolic levels, mystification and demystification, and dystopia and utopia. Finally, the paper looks at Facebook's practices as an exemplification of such a dynamic. In fact, some Facebook users, while exploited in the unpaid production of content for this platform, also follow a liberal normative thrust that frames Facebook's usage as a form of social work towards a better society. 


\section{Labour in the Context of Informational Capitalism}

In recent times, several scholars have tried to understand the new media environment through the perspective of what Castells (2000) defines as "the process of capitalist restructuring undertaken since the 1980s", otherwise called "informational capitalism" (18). Similarly to the notion of "post-industrial society" (Bell 1973), "information society" (Webster 2002), informational capitalism refers to the increasing prominence of information and communication within capitalism under conditions of globalization and rapid technological development.

In such a new configuration, the worker becomes increasingly involved in the tasks of handling, distributing, and creating knowledge (Mosco and McKercher 2007; Florida 2002). Consequently, labour progressively undertakes relational, cognitive, imaginary and sensemaking, affective, and caring activities (Virno 2004). Such a new productive mode of production tends to overcome the separation "between working-time and lifetime, working place and life place, and production and reproduction" (Morini and Fumagalli 2010, 240).

In the field of media studies, much of the interest about informational capitalism could be explained in relation to the alleged capability of new media to radically redefine the meaning of mass communication and blur the boundaries between the moment of production and moment consumption, the moment of dissemination, and reception of the message. I am particularly interested in the one characterized by a normative liberal thrust. In fact, one of those narratives depicts the mediated communication of Web 2.0 platforms as a much more egalitarian process, in which the audience operates at the same level of the traditional institutional communicator as well as producing more space for individual expression (Napoli, 2008). Such a perspective reverberates with a conceptualization of an (politically and socially) emancipated audience who "does things with media" as opposed to "be[ing] used by media".

In reaction to such narrative, several scholars have scrutinized new media practices from the point of view of power, labour, and value creation (see eg, Arvidsson and Colleoni, 2012; Cohen, 2008; Dyer-Witheford 1999; Fuchs, 2010, 2012; Hesmondhalg, 2010; Margonelli 1999; Napoli, 2008; Petersen 2008; Scholz 2008; Terranova 2004; Willmott 2010; Zwick et al. 2009). Concerned with the political economic of new media tendency to capture value outside the traditional productive process; in this section, I briefly review Fuchs' $(2010,2012)$ contribution, the two sided notion of free labour formulated by Terranova (2004) as well as those concepts that resonate with the utopian and dystopian discourse that, according to Mosco, surrounds modern media.

\subsection{Valorising Digital Labor}

According to Scholz (2012) digital labour has become one of the key concepts in order to both understand the political economic environment of new media and the discussion around it. One of the most critical positions in such a debate states that internet has been incorporated in a dominant corporate model of capital accumulation, which is grounded on the exploitation of unpaid labour of "prod-users," ie, the activity of creating content by users while involved in activaties such as blogging or social networking. I find particularly representative of such a discussion Fuchs' perspective (2010, 2012).

Fuchs (2010) applies Marxian theory of value to examine the unpaid labour of web 2.0 users, which while constituting an important factor of production of value, remains unpaid and exploited. Fuchs' essay pushes against several tendencies. On the one hand, the paper rejects a literature (Bell, 1973; Florida, 2002; Beck, 1992) that "negates the relevance of class analysis in informational society" (180). On the other hand, it reacts against the emancipatory interpretation of free labour, which, as Andrejevic observes (2008), recalls the ideologically loaded media studies notion of "active audience". By contrast, the author considers prod-users as exploited knowledge workers, a class fraction of the multitude (Hardt and Negri 2000), for "in informational capitalism, knowledge has become a productive force, but knowledge is produced not only in corporations in the form of knowledge goods, but also in everyday life" (186). 
According to Fuchs, capital freely consumes the commons (product of natural and societal process such as water or education) freely created by prod-users. Drawing on Smythe's seminal essay (1977), Fuchs argues that users are sold as a commodity to advertisers. However, if in the original analysis of TV practices, the audience only consumed media material, in the case of new media, the audience assumes the role of producing content, being engaged in permanent creative activity, communication, community building, and content production. In conclusion, to paraphrase Jhally and Livant (1986), Fuchs critically examines new media by focusing on what media take out from audience (value) rather than what media are suppose to put into it (messages).

\subsection{Why Prod-Using?}

Why prod-users work for free? What drives them? Arvidsson and Colleoni (2012) would claim that the typical subjectivity operating with web 2.0 media tends to value affective relationship so that Facebook or YouTube users do not really reason in terms of labour but rather in terms of building and enjoying a sense of community. On the other hand, Fuchs (2012) provides another plausible explanation that draws on Bourdieu's political economic analysis of power: if we are to acknowledge the existence and relevance of affective relations then, social, cultural. and symbolic capital become necessities and scarce goods. Therefore, one could say that prod-users are in fact compelled to "work" for new media in order to accumulate social relations (social capital), qualification, education, knowledge (cultural capital), and reputation (symbolic capital) (for instance, frequently job candidates are evaluated based on the their social media activity). From this point of view, affective relations can be effectively understood by Marxian theory of value because the effort to build them and accumulate social capital requires labour time and should be understood in the general framework in which "presumption" activities (Fuchs, 2013) work in the capitalist regime of time.

In my view, both desire of sociability and exploitation should be combined in order to explain the set of motivations that drives prod-users and that requires an understanding of ideology capable of synthetizing what I consider some dualisms characterizing digital labour: coercion and consent, and false and "true" consciousness. Thus, in relation to the classic Marxist perspective according to which exploited subjects "simply don't know," and Žižek's reformulation "they do know but they still do it", I claim that a functionalist understanding of ideology-ie, stressing the instrumental function of ideology in re-producing the dominant relations of productions-must also consider a normative set of motivations that cannot be considered as completely fictitious nor completely cynical and that, in this particular case, resonate with (neo-)liberal ideology.

\section{Ideology as a Material and Mediating Force}

As Garnham (2000), Mosco (2011), and Miller (2011) have noticed, the great majority of communication and media studies have been consistently affected by a chronic dis-interest about labour and material production. In this sense, against a mostly idealist approach to ideology characterizing this field, this paper explores the role of ideology in materially reproducing the conditions of production of digital labour. As I will show later on, ideology is in my view, what mediates two co-existing aspects in web 2.0 activities: what Fuchs and Sevignani would define as "working" and "labouring" and what could be synthetized in Terranova's concept of "free labour".

\subsection{The Idealism of Ideology in Media Studies}

In the last decades, the interest in theorizing the ideological agency of media in both reproducing and transforming a given society has been impelled by the seminal contributions of several Marxist authors. Some of those are Althusser and his theorization of media as Ideological State Apparati (1970), Gramsci's study of cultural hegemony and the study of media as the most dynamic ideological force (1971), Horkheimer and Adorno's conceptualization of media as culture industry that created a pervasive understanding of the world (1970), 
Debord's definition of capitalism as a mediatic spectacle that promotes consumer culture and a highly fetishized representation of social reality (1968), and finally Williams's theorization of cultural materialism (1977), which, building on Gramsci and Goldman, re-positions communication at the core of material production of life.

Such literature should be credited to have "emancipated" media and communication process from the superstructural/epiphenomenal condition. However, as Peck (2006), Artz, Maceck and Cloud (2006) and Aune (2004) claim, most of media research seems to still operate within the idealist assumption that "consciousness determines social being." In many instances, the interest of media scholars for ideology is more focused on the communication process that channels ideology rather than ideology itself. As a result, ideology is almost never linked to labour and material production but reduced to a "result" within the still powerful tradition of mass communication effects.

Exemplary of how media studies tend to interpret ideology is Hall's very influential approach. According to Gunster (2004), whereas Hall initially drew from Althusser's concept of Ideological State Apparati (1970) and Gramsci's concept of cultural hegemony (1971), subsequently his understanding significantly distanced from the other two authors. Hall in fact, passes from an Althusserian understanding of ideology-a highly contradictory living practice that in the last instance reflects the dominant relations of production-to a pluralist approach that describes the confrontation among competing ideologies. Thus, whereas for Althusse, ideology could be distinguished from science, and for Gramsci the ideologically loaded common sense had to be distinguished from a "good common sense", for late Hall, no ideology has the guarantee of becoming dominant and no worldview can definitively raise (good) consciousness.

Thus, "late" Hall's interest is not so much about the relationship between ideology and an alleged objective reality but rather on an ideologically constituted environment that can never been completely escaped. In this context, for Hall, media are involved in "the politics of signification", and "cultural wars" (Davidson Hunter 1991), according to which media produce images of the world that not only give events particular constitutive meaning. As Hall (1982) puts it, "Representation is a very different notion from that of reflection. It implies the active work of selecting and presenting, of structuring and shaping; not merely the transmitting of an already-existing meaning, but the more active labour of making things mean" (64).

As Crocteau (2002) notices, "most media scholars use ideology as a concept to understand representation, focusing on how media texts signify. Therefore, they are in most cases prone to treat ideology in idealist terms, because the key issues regards ideas reflected on texts, images and semiotic codes, their interpretations, their representation, their signification: "For ideological analysis, the key is the fit between the images and words in a specific media text and ways of thinking about, even defining, social and cultural issues" (160). Thus, paradoxically enough, if for a long time Marxist scholarship had been accused of embracing a "crude materialism" that anti-dialectically privileged the material over the mental/symbolic, the economic over the cultural (Godelier 1986), in media studies the opposite seems to be true. That is to say that consciousness is privileged over social being.

However, the well-known reverse of the formula-"social being determines consciousness"-cannot be accepted uncritically or without qualifications. In fact, Marx and Engels did not enter a conversation dominated by the Hegelian "Geist" and Kantian "a priori" forms, to replace absolute idealism with absolute materialism as they argue that "The production of ideas, of conceptions, of consciousness, is at first directly interwoven with the material activity and the material intercourse of men, the language of real life" $(1977,164)$. In other words, Marxian historical materialism does not necessarily treat ideas and consciousness as mere appearance of a "material essence" because they, in turn, contribute to reproducing the social being. Their intervention meant to criticize the tendencies of German contemporary theorist to understand consciousness as process abstracted from the real and material processes of history.

According to Marx (1977), grasping this meant acquiring superior and standpoint that could allow scientific explanation of socials phenomena and even prediction. Conversely, failing to realize such a nature of social reality and therefore abstracting it produces ideology, 
a cognitive mistake: If in all ideology men and their circumstances appear upside down as in a camera obscura, this phenomenon arises just as much from their historical life process as the inversion of objects on the retina does from their physical life process (47). The mistake is not so much about giving credit to a particular ideology or a worldview as opposed to material circumstances, but rather abstracting the former from the latter.

Equally telling is Engels's statement that the mistake of the subject living by an ideology is due to be centred in its own artefact self-referential world. Again, the problem found in it is not necessarily about ideas, because without ideas the architect could not be distinguished from the bee, but about ideas abstracted from real material conditions and relationships: "Ideology is a process accomplished by the so-called thinker consciously indeed but with a false consciousness. The real motives impelling him remain unknown to him; otherwise it would not be an ideological process at all. Hence he imagines false or apparent motives. Because it is a process of thought he derives both its form and its content from pure thought, either his own or his predecessors" (Letter to Mehring 1893, 2).

So, the question then is whether a worldview driven by a historical materialist approach, therefore not abstracted from material conditions, could be considered as a "good" ideology, in other words to become aware? In a renewed passage Marx seems to suggest that, therefore implying an understanding of ideology that frictions with the conceptualization of ideology as false consciousness: The distinction should always be made between the material transformation of the economic conditions of production [...] and the legal, political, religious, aesthetic, or philosophic-in short, ideological-forms in which men become conscious of this conflict and fight it out (Williams, 1985 157).

Williams states (1985) that this more neutral understanding of ideology would characterize some important Marxist scholarship of the last century as it is exemplified by the fact that for Lenin key aspect of struggles translated into the clash between competing ideologies, or for Gramsci exists a common sense as naturalization of hegemony and good common sense. From the perspective that I am trying to define in this paper, ideology is understood as both: it is actually the mediation between awareness and the false consciousness, between theoretical knowledge and empirical experience because as Gramsci claims, the awareness about the historical and materialist nature of social reality takes place in a continuous interaction with a given ideologically driven worldview and historic specific social conditions.

Accordingly, in the historic-specific context of informational capitalism, the worldview I describe combines the Marcuse (1965) and Horkheimer and Adorno (1974) account of how late capitalism fuses labour and leisure time and Mosco (2005), Bloch (1986), and Jameson (1991) cultural diagnostics of the function of utopia. According to such view, digital workers do not only labour for "fun", and the instrumental acquisition of social cultural and symbolic capital (Fuchs, 2012), but also are motivated by the technological utopianism that connects new media with the hope to regenerate civil society, Gemeinschaft, democracy and affective relations. In fact, by generating content, Web 2.0 users also generate subjectivity (Coté and Pybus, 2007) and an ideology that ethically signifies knowledge work as a kind of social work towards a utopic society emancipated by technology.

In order to explain the way I understand ideology I find Eagleton's (1991) taxonomy very useful. The author provides six possible ways to conceptualize ideology, from a more general to a more specific kind of phenomenon: first it could be defined as "general material process of production of ideas" (28); according to the second definition those ideas could pertain to a "socially significant group" (29); according to the third definition, this group may actively aim at the "promotion and legitimation" (29) of such an ideology; according to the fourth such a class project may involve "the complicit of subordinated classes" (30); according to the fifth, such a project can also entail deceptive aspects such as "distortion and dissimulation" (30); finally according to the sixth definition, ideology may be systematically reproduced by arising "from the material structure of society as a whole" (30).

In relation to such a conceptual mapping, my understanding of ideology would try to synthetize different aspects of those definitions: it consists of a class-based project, which aims at a hegemonic ruling in the Gramscian sense, thus implying the effort to combine force and consent (of subordinated classes), as well as trying to symbolically and materially universal- 
izing its world view. However, from a longitudinal perspective, such a worldview cannot be easily tied to a class because it becomes structurally reproduced by all sorts of productive and consumptive practices, as in the case of commodity fetishism. Thus, in my definition, ideology consistently aspires to hegemony, it is the "particular" that aspires to a "general," the "subjective" that aspires to the "objective", the "explicit" that aspires to be "implicit", and finally, the "cultural" that aspires to become "natural."

In relation to digital labour, such a position echoes the Marxian notion of "productive consumption", in the sense that audience produces consciousness but also articulation of ideas by consuming commodified culture (in Nixon, 2012 443). Marx and Engels in German Ideology (2001) maintain that the production of consciousness and the production of ideology are tightly linked to the concrete human activity: the production of ideas, concepts, and consciousness is, first of all, directly interwoven with the material intercourse of man, the language of real life. Conceiving, thinking, the spiritual intercourse of men, appear here as the direct efflux of men's material behavior [...] Consciousness does not determine life: life determines consciousness (35-36).

However, the worker's consciousness and his/her adoption of specific worldviews does not passively reflect "real life" but interacts with it and therefore, cannot be simply reduced to an instrumentalized epiphenomenon of productive logics. Following Bloch's (1986) consideration of the complexity of the ideological phenomenon, I would argue that the ideology of the prod-users is not simply "false consciousness" in the same way as consciousness is not simply "false ideology" because aside from its concealing of exploitation, it comprises a genuine desire of the community for a better society. As Kellner and O'Hara explain (1976), Bloch considers ideology as an ambiguous two-sided phenomenon as it encompasses distortion, mystifications, techniques of manipulation, and domination, but it also incorporates a utopian residue. Thus, the cognitive error of ideology and the cognitive accuracy of consciousness (as opposed to false consciousness) maybe distinct but also are highly intertwined. In relation to my previously provided definition of ideology, it is the aspiration to become holistic that allows ideology to resonate with utopia.

In Part III of his Principle of Hope, Bloch applies his utopian reading to all sorts phenomena associated to ordinary life and popular mediated culture: advertisements, circus, fairy tales, illustrated magazines, the cinema, and the theatre. For instance, Bloch understands all consumer products to take care of the body as means to transcend the material corporality of the body. Just like in daydreaming, ideology is characterized by the tension between past and future. On the one hand, it operates in a pre-existing framework of ideas and practices; on the other hand, when embraced by particular subjects, it becomes a projection for the future, an imagine of what life could be with for instance more money, with a beautiful body, or with a revolution. From this point of view, ideology is for Bloch a very dynamic ensemble of lived relations and concrete possibilities more than is more imaginary in the Lacanian sense than simply deceptive.

Such a process of production of ideology and consciousness generating through the produsers' activity does not take place in vacuum, but is immerged in a pre-existing ensemble of ideas and practices. In other words, it interacts also with previous existing worldviews that contribute to give meaning to both media and their usages. Drawing on Mosco (2005), I see in media practices, both the resurgence of a liberal public sphere ideology that tries to colonize all social experiences (Negt and Kluge, 1993) and the assertion of a technological utopianism that equates hi-tech progress with social progress and that consistently manifests with the introduction of (relatively) new means of communication.

So how does this interaction between "practical consciousness" and practical activity more concretely function? In the next section, I try to clarify that with the idea that ideology mediates between two distinct but interconnected aspects of Web 2.0 activity: unpaid labouring and social working. 


\subsection{Free Labour as Working and Labouring}

By the review just considered, I meant to point out how in media studies ideology tends to be treated in idealist ways. Conversely, I want to approach ideology by the same question Althusser poses in his essay on Ideological State Apparati (1970), as a question about material "re-production of the conditions of production" (1). In the specific case of user-generated content this implies considering how to reproduce that specific subjectivity that drives a Web 2.0 users to accept a condition of unpaid and exploited labour.

I believe that the Terranova's (2004) notion of free labour points to one of those ideological conditions of reproduction of the system of valorization of prod-users, that is a production of the production of consciousness and ideology to understand the consensual reproductive aspects of digital labouring and the production of neoliberal hegemony. In fact, such a framework allows combining the objective element of exploitation and the subjective element of consciousness and ideology.

In the specific context of digital labour, the reproductive function of ideology reveals itself in its capability of conciliating the exploitative and the normative aspect of "free labour". More than a decade ago, Terranova (2000) published an influential essay that tried to make sense of the media practices of Internet users. According to the author, the so-called "net slaves" were exemplar of the so-called digital economy. In relation to idealist tendency previously mentioned in media studies, Terranova (2000) finds in Internet more than ideas, but a place "animated by cultural and technical labor through and through, a continuous production of value that is completely immanent to the flows of the network society at large" (35). The Internet is materially arranged in "out-ternet" "the network of social, cultural, and economic relationships that crisscrosses and exceeds the Internet-surrounds and connects the latter to larger flows of labour, culture, and power" (34).

The objective of Terranova is to map a conceptual and material territory that stands in between production and consumption, exploitation, and a promise of liberations. It is a concept that tried to mediate apparent dualism. In fact, echoing the autonomist Janus faced position, free labour "has something of a double meaning" (Hesmondhalg, 2010, 273). It refers to unpaid work, but, in line with Terranova's explicitly autonomist sympathies, it also refers to the way in which labour cannot be fully controlled, because of capital's continuing and problematic reliance on it. On the other hand, drawing from Hardt, Negri, Lazzarato, and Virno seem also to implicitly believe that immaterial labour can provide the social pre-conditions for a spontaneous form of communism. Thus "free labour" is both captive and (potentially) free.

Terranova tries to make sense of a historic specific reality that presupposes the existence of Internet and the post-fordist capitalist mode of production. However, in my view, her intuition goes further than that and speaks about a dialectical way to conceive human productive activity. In this sense, Fuchs and Sevignani (2013) spell in very clear ways the dialectical aspects of producing. With their investigation on how Marx (and Engels) conceives human practical activity, they suggest the need to distinguish between "labour" and "work". Fuchs and Sevignani's contribution can clarify the two aspects of free labour in the digital environment. They distinguish the two concepts as follows: "Labour is a necessarily alienated form of work, in which humans do not control and own the means and results of production. Work in contrast is a much more general concept common to all societies. It is a process in which humans in social relations make use of technologies in order to transform nature, culture and society in such a way that goods and services are created that satisfy human needs" (240).

The two authors point out how productive work seems to be an inherent characteristic of human beings, which then develop differently according to different social and historical contexts. However, work is not simply the general "anthropological" conceptualization of human productive activity. In relation to how historically labour developed in capitalist societies, work remains as more positive alternative. In fact, if it is true that in the Economic and Philosophic Manuscripts Marx says that one major alienation is both from the worker's own work and own product of work, then work, is understood not only as necessity due to the inherent scarcity that characterizes our material environment, but also as a chance of human expression and signification, a chance to make of the product into signified matter. Instead waged labour 
appears as alienated work, the denial of the latter. Thus, one can find a dialectic unity of alienation and emancipation, which seems to be inherent in how human practical activity historically developed in capitalist societies.

In the concrete social relations that surround digital labour, working and labouring are in fact synthetized: on the one hand, the web 2.0 user is unpaid, alienated from his/her own product and from the work process and becomes a commodity sold to the advertising industry; on the other hand the Web 2.0 user is a social worker that constructs his/her own identify by constructing the social environment around but also is driven by the idea of digital citizenship and the fact the content that he/she produce has a social and political value. Thus, the web 2.0 user is alienated by his/her unpaid labouring but feels emancipated by his/her social working. As I will show in the next section Facebook eloquently exemplifies such a condition.

\section{Face to Face with Facebook}

Since its first formulations, Liberalism has consistently been capable of fusing together a political and an economic project. When, for instance, Milton in his manifesto of 1644 Aeropagitica demanded a "free market of good and ideas" implied that the liberalization of the market and the public sphere were tightly connected. In fact, the link between the two aspects is so profound that both in the public and academic discourse the market frequently becomes metaphor for democracy and democracy becomes a metaphor for the market.

In this sense, communication technology has very often embodied such a link in powerful ways. Facebook is a perfect example, as its rhetoric intermeshes together political and economic arguments. Kushner in a Rolling Stone article applauded Facebook in terms of "citizen" and "consumer" choice (2006): "the long epoch of top-down culture [...] is fading faster than anyone predicted. The more vibrant world is bottom up, powered by the people." As Cohen notices (2008), innovations in information and communication technology tend to be accompanied by the teleological narratives of progress and human perfectibility.

Indeed, Facebook reflects the liberal normative social projects to liberate men through the market, through Smith's public use of instrumental and individualist reason, through technology and communication represent. Those are all facets of the liberal discourse/ideology of modernity (Passerin and Benhabib, 1997). They are at same time ideological fictions but also relevant promises that have historically mobilized people for quite some time now and they still operate through the utopia of media as technological promises of human comprehension and social pacification. The exemplification of such a complex sentiment is provided by one of the most popular Web 2.0 platforms, Facebook, that indeed combines both exploitative and utopic aspects of media.

On the one hand, Facebook outsources and crowd-sources the work of media production through the producer-consumer, a practice of cost reducing that not accidentally coincided with rising layoffs in media industries (Deuze 2007). As Huws notices (2003) the exploitative aspect of unpaid labour in new media comes from a general tendency of capital to offload labour cost onto consumers juts like on the case of self service gasoline stations, ATM, grocery check out which "burden the consumers of unpaid labour" (69). Such a system of exploitation of prod-users has in the case of Facebook exhibited itself rather explicitly as in the case of the program Facebook Diaries (Cohen 2008), which asks Facebook users to send stories and therefore "participate" to a contest that rewards the best stories by broadcasting them on TV.

On the other hand, as Kessler (2007) notices, Zuckerberg, the founder of Facebook, consistently utilizes rhetoric of novelty, social change, and promise of social amelioration through media technology, which, in its clear instrumentality, also resonates with genuine existing democratic sentiments. In the Facebook "manifesto," (2007) the founder describes the "social mission" of the platform as it follows:

Facebook aspires to build the services that give people the power to share and help them once again transform many of our core institutions and industries [...] We believe building tools to help people share can bring a more honest and transparent dialogue around government that could lead to more direct empowerment of people, more accountability 
for officials and better solutions to some of the biggest problems of our time. By giving people the power to share, we are starting to see people make their voices heard on a different scale from what has historically been possible. These voices will increase in number and volume. They cannot be ignored. Over time, we expect governments will become more responsive to issues and concerns rose directly by all their people rather than through intermediaries controlled by a select few (1).

Zuckerberg's rhetorical arguments makes leverage on the technologic utopianism which recovers liberal ideology through the reassertion of the public sphere and Kantian publicity, which is represented in the text by both the use of reason in public and the idea of political power under public scrutiny. Such a rhetoric is also conveyed by a more general narrative of new media, which are often described as "Web 2.0", "social media", "participatory media", "citizen journalism", "user generated content", "user driven innovation", or "social software". Such a civic consciousness ultimately re-articulates in terms of "ethical work" and "ethical citizenship" the (neo-)liberal ideological fiction of a civic society not ruled by the state as external apparatus but by the market as an internal, ethical, self-sufficient, and self-balancing system.

Such a normative thrust is not simply present in the rhetoric of its founder but also in the daily practices of Facebook users. Aside the significant aspect of management impression according which users utilize this platform to construct, negotiate, and reproduce a given identity, many users understand the function of "sharing" links and content as a way to establish a platform for discussion of matter of public interests, to sensitize specific issues. Furthermore, as the study conducted by DeRosa (2013) confirms, people use web 2.0 platform in order to construct a new utopic understanding of citizenship, a digital citizenship that reinterpret democratic deliberation as "e-democracy". As Dean (2009) observes social media are less places enhancing critical debate than platforms devoted to corporate profit. However, as I tried to demonstrate they also work as platforms that provide an ideological rationalization and moralization of "free labour" because they produce the impression of subjective visibility and social and political agency.

Thus, as Bloch recognizes, although often mirroring "how the ruling class wishes the wishes of the weak to be" (1986a: 13), the ideologies in Facebook can also provide a "transition' stage and display a drive towards a better life, and real possibilities to transform societies. In Facebook, Bloch $(2004,40)$ would probably find two different utopia-informed ideological aspects. First, via Facebook users embrace what Bloch defines as "wish-fulfillment" aspects, which consist in the elimination of the roots of human un-happiness such as the "arcana imperii" characteristic of power, the alienation and social solipsism allegedly characterizing modern mass societies. The second utopian aspect Bloch would find operates by "constructing" (40) the utopia; in the case of Facebook, by contributing to re-arrange labour, social organization, civic order, and what Aristotle defined as Politeia.

The apparent openness of Facebook to whatever content or community organization would appear as promise of the reality "not yet" realized. The "anticipatory consciousness" (Bloch, 1986) of Facebook users perceives the unrealized emancipatory potential in Facebook. Indeed, as already mentioned, Facebook is far from being a public sphere for critical thinking but in such an environment the users experience the ideological surplus value of the bourgeois notion of citizenship with its individual rights, civil liberties, and actively engaged autonomy expressed something more than mere legitimation and apologetics for bourgeois institutions and practices.

Thus, what the example of Facebook points out is an ambiguous reality. On the one hand, Facebook can and should be considered as further rationalization, colonization, and commodification of the Lebenswelt. On the other, the fact that our private sphere becomes a commodity that is a sold in a particular market makes that market as a Miltonian liberal arena in which, aside from goods, ideas can, wishful-thinkingly enough, move freely. As a result, the unpaid and exploited labour of generating content also gives the impression of a social working towards a more democratically progressive society. 


\section{Conclusions}

According to Sartre (1976), practical human activity represents the most concrete experience of dialectics. The inherent condition of scarcity of our world, ie, the fact that there is not enough for everybody, stands as a fundamental negation of the human existence, which is in turn negated by way of praxis, our work. Productive praxis expresses for Sartre a statement of human emancipation. However, the negation of the negation, this positive act of human self-liberation contained in praxis, should also be understood in the continuous and inescapable production of its antithesis: an inertia produced by the traces of mine and somebody else praxis that go against my objectives.

In this sense, this paper tried to point how digital labour dialectically contains both the subjective dimension of purposeful and potentially emancipatory work and the objective condition of unpaid labour, generating content valorized for the benefit of others. Thus, the practical experience of digital labour may reproduce in the consciousness and the ideology of the Web 2.0 such a dialectical experience of making things: a never-ending process of subjectivization and objectification, appropriation and alienation, estrangement and partial reconnection, coercion and consent. In fact, what is being produced in the process of generation of content is not just a "update of Facebook status" but also a particular understanding of the world that simultaneously contributes to reproduce the condition of production of content, ie, of valorization and monetization of digital labour, and aspires to realize a social political project such as the liberal one.

Such a consciousness is not plainly false, but is rather contradictory. On the one hand, as Althusser would say, the consciousness generated during the productive consumption of Web 2.0 users "represents the imaginary relationship of individuals to their real conditions of existence" $(1970,52)$ because the moralized mimicry of social working, while generating content, hides dimension exploitation, therefore a level false consciousness. On the other hand, prod-users 'consciousness and ideology seem to draw from existing genuine desires mediated by what Mosco considers as technological utopianism (2005), an (neo-)liberal understanding of knowledge work as social work in post Welfarist context, and the prod-users' rational motivation to accumulate social, cultural and symbolic capital.

To conclude, this paper has certainly not tried to suggest that informational capitalism is "ambiguously bad". Indeed, this mode of production is bad enough as it still functions with the perverse logic of socializing production and privatizing the gain from that. Capitalism must be overcome and the intellectual wealth produced by knowledge workers gathered into commons, become a collective resource. The "moral of the story" of this paper is in many ways a caveat: the subsumption process of capital is strong enough to produce utopic and moralized aspects of it; strong enough to produce aspects of emancipatory work within exploited labor. Thus, as many dialectical narratives do, mine suggests that if are theoretically able to distinguish destructive and constructive aspects in human practical activity, in the concrete historical experience, the desired replacement of alienated labour with liberatory and selfexpressive work may not be as straightforward and linear as we may think.

\section{References}

Althusser, Louis. 1970. Lenin and Philosophy and other essays. NY \& London: Monthly. Andrejevic, Mark. 2008. Watching Television without Pity. Television \& New Media 9 (1): 24-46.

Artz, Lee, Maceck, Stephen and Cloud, Dana (eds). 2006. Communication and Marxism: The Point is to Change it. New York: Peter Lang.

Arvidsson, Adam and Eleanor Colleoni. 2012. Value in Informational Capitalism and on the Internet, The Information Society: An International Journal 28 (3): 135-150.

Aune, James. 2004. Rhetoric and Marxism. Boulder: Westview Press.

Bloch, Ernst. 1986. The Principle of Hope. Cambridge, MA: MIT Press.

Caraway, Brett. 2011. Audience Labor in the New Media Environment: A Marxian Revisiting of the Audience Commodity. Media, Culture \& Society 33 (5): 693-708.

Castells, Manuel. 2000. The Rise of the Network Society. Malden, MA: Blackwell Publishers.

Chomsky, Noam. 1999. Profits over People—Neoliberalism and Global Order. New York: Seven 
Stories Press.

Bell, Daniel. 1973. The Coming of Post-industrial Society. Hammondsworth, England: Penguin.

Coté, Michelle and Jean, Pybus. 2007. Learning to Immaterial Labour 2.0: Facebook and Social Networks Ephemera. Theory and Politics in Organization 7 (1): 88-106, 83.

Cohen, Nicole. 2008. The Valorization of Surveillance: Towards a Political Economy of Facebook. Democratic Communiqué 22 (1): 5-22.

Dean, Jody. 2009. Democracy and Other Neoliberal Fantasies: Communicative Capitalism and Left Politics. Durham: Duke University Press.

De Rosa, Rosanna. 2013. Cittadini Digitali. L'agire Politico al tempo dei Social Media. Napoli, Apogeo.

Deuze, Mark. 2007. Toward an Ethics of the Sociable Web: A Conversation between Trebor Scholz and Mark Deuze. Accessed June 3, 2013. http:// https://mailman.thing.net/pipermail/idc/2007July/002652.html

Dyer-Witheford, Nick. 1999. Cyber-Marx. Cycles and Circuits of Struggle in High-Technology Capitalism. Urbana: University of Illinois Press.

Eagleton, Terry. 1991. Ideology: An Introduction. London: Verso.

Florida, Robert. 2002. The Rise of the Creative Class. New York: Basic Books.

Fuchs, Christian. 2010. Labor in Informational Capitalism and on the Internet. The Information Society: An International Journal 26 (3): 179-196.

Fuchs, Christian. 2012. With or Without Marx? With or Without Capitalism? A Rejoinder to Adam Arvidsson and Eleanor Colleoni. tripleC_Communitcation, Capitalism \& Critique 10 (2): 633-645.

Fuchs, Christian and Sebastian Sevignani. 2013. What is Digital Labour? What is Digital Work? What's their Difference? And why do these Questions Matter for Understanding Social Media? tripleC_Communitcation, Capitalism \& Critique 11 (2): 237-293.

Godelier, Maurice. 1986. Mental and Material. London: Verso.

Gramsci, Antonio. 1971. Selections from the Prison Notebooks. New York: International Publishers.

Gunster, Shane. 2004. Capitalizing on Culture: Critical Theory for Cultural Studies. Toronto: University of Toronto Press.

Habermas, Jürgen. 1991. The Structural Transformation of the Public Sphere: An Inquiry into category of Bourgeois Society. Cambridge, MA: MIT Press.

Hardt, Michael and Antonio Negri. 2000. Empire. Cambridge, MA: Harvard University Press.

Harvey, David. 1989. The Condition of Postmodernity. London: Basil Blackwell.

Hesmondhalg, David. 2010. User-Generated Content, Free Labor and the Cultural Industries. Ephemera 10 (3/4): 267-84.

Horkheimer, Max and Theodor Adorno. 1974. The Dialectics of Enlightenment. London: Verso.

Huws, Ursula. 2003. The Making of a Cybertariat: Virtual Work in a Real World. New York: Monthly Review Press.

Jhally, Sut and Bil Livant. 1986. Watching as Working: The Valorization of Audience Consciousness. Journal of Communication 36 (3): 124-143.

Kellner Douglas and H. O'Hara. 1976. Utopia and Marxism in Ernst Bloch. New German Critique 9: 11-34.

Lazzarato, Maurizio. 1996. Immaterial Labor. In Radical thought in Italy, edited by P. Virno and M. Hardt. Minneapolis: University of Minnesota Press.

Lukacs, Georg. 1971. History and Class Consciousness: Studies in Marxist Dialectics. Cambridge, MA: MIT Press.

Marcuse, Herbert. 1965. Remarks on a Redefinition of Culture. In The Essential Marcuse: Selected Writings of Philosopher and Social Critic Herbert Marcuse, edited by Andrew Feenberg and Wiliam Leiss, 13-31. Boston, MA: Beacon Press.

Margonelli, Luca. 1999. Inside AOL's “Cyber-Sweatshop”. Wired 7 (10). Accessed June 12, 2013. http://archive.wired.com/wired/archive/7.10/volunteers.html

Marx, Karl. 1867. Capital: A Critique of Political Economy. Vol.1. Translated by Ben Fowkes. London: Penguin Classics.

Marx, Karl and Friedrich Engels. 2001. The German Ideology Part One. New York: International Publishers.

McKercher, Catherine and Vincent Mosco, eds. 2006. Special Issue on the Laboring of Communication. Canadian Journal of Communication 31(3).

_ 
Morini, Cristina and Andrea Fumagalli. 2010. Life put to Work: Towards a Life Theory of Value. Ephemera 10 (3/4): 234-52.

Mosco, Vincent. 2005. The Digital Sublime-Myth, Power, and Cyberspace. Cambridge, MA: MIT Press.

Muehlebach, Andrea. 2012. The Moral Neoliberal: Welfare \& Citizenship in Italy. Chicago: Chicago University Press.

Napoli, Paul. 2010. Revisiting "Mass Communication" and the "Work" of the Audience in the New Media Environment. Media, Culture \& Society 32 (3): 505-516.

Negt, Oskar and Andres Kluge. 1993. Bourgeois and Proletarian Public Sphere. Minneapolis: University of Minnesota Press.

Nixon Brice. 2011, Dialectical Method and the Critical Political Economy of Culture. tripleCCommunication, Capitalism \& Critique 10 (2): 439-456.

Passerin, Maurizio \& Seyla, Benhabib, eds. 1997. Habermas and the Unfinished Project of Modernity: Critical Essays on the Philosophical Discourse of Modernity. Cambridge, MA: MIT Press.

Peck, Janice. 2006. Why We Shouldn't Be Bored with the Political Economy versus Cultural Studies Debate? Cultural Critique 64: 92-126.

Peters, John. 1999. Speaking into the Air: A History of the Idea of Communication. IL: University of Chicago Press.

Petersen, Soren. 2008. Loser Generated Content: From Participation to Exploitation. First Monday 13 (3). Accessed June 12, 2013. http://firstmonday.org/article/view/2141/1948

Resnick, Stephen and Richard Wolff. 1987. Knowledge and Class: A Marxian Critique of Political Economy. Chicago: University of Chicago Press.

Scholz, Trebor. 2008. What the MySpace Generation Should Know About Working for Free. Accessed February 12, 2011. http://collectivate.net/the-social-web/

Smythe, Dallas. 1981. On the Audience Commodity and its Work. In Media and Cultural Studies, edited by M. G. Durham, and D. M. Kellner, 230-56. Malden, MA: Blackwell.

Terranova, Tiziana. 2000. Free Labour: Producing Culture for the Digital Economy. Social Text 18 (2): 33-57.

Terranova, Tiziana. 2004. Network Culture: Politics for the Information Age. London: Pluto Press.

Virno, Paolo. 2004. A Grammar of the Multitude. London: Pluto Verso.

Webster, Frank. 2002. Theories of the Information Society. New York: Routledge.

Wennerlind, Carl. 2002. The Labor Theory of Value and the Strategic Role of Alienation. Capital \& Class 26 (2): 1-21.

Williams, Raymond. 1985. Keywords: A Vocabulary of Culture and Society. Revised edition. New York: Oxford University Press.

Wilmott, Hugh. 2010. Creating Value Beyond the Point of Production: Branding, Financialization and Market Capitalization. Organization 17 (5): 517-42.

Žižek, Slavoy. 1989. The Sublime Object of Ideology. London; New York: Verso.

Zompetti, Joseph. 1997. Toward a Gramscian Critical Rhetoric. Western Journal of Communication 61.

Zuckerberg, Mark. 2007. Keynote Speech Delivered at the f8 Conference at the San Francisco Design Centre. Accessed June 6, 2013. https://developers.facebook.com/docs/graphapi/reference/v2.0/video

Zwick, Detlev, Samuel Bonsu and Aaron Darmondy. 2009. Putting Consumers to Work. "Co-creation" and New Marketing Govern-Mentality. Journal of Consumer Culture 8 (2): 163-96.

\section{About the Author}

Marco Briziarelli

is an assistant professor at the University of New Mexico's Communication and Journalism department. He studies and teaches courses on media theory, political economy of media and media and social movements. 